\title{
Effect of diet and individual dietary guidance on gastrointestinal endocrine cells in patients with irritable bowel syndrome (Review)
}

\author{
TAREK MAZZAWI ${ }^{1,2}$ and MAGDY EL-SALHY ${ }^{1-3}$ \\ ${ }^{1}$ Division of Gastroenterology, Department of Clinical Medicine, University of Bergen; \\ ${ }^{2}$ National Centre for Functional Gastrointestinal Disorders, Department of Medicine, \\ Haukeland University Hospital, Helse-Bergen, 5021 Bergen; ${ }^{3}$ Division of Gastroenterology, \\ Department of Medicine, Stord Hospital, Helse-Fonna, 5416 Stord, Norway
}

Received March 21, 2017; Accepted July 7, 2017

DOI: $10.3892 /$ ijmm.2017.3096

\begin{abstract}
Irritable bowel syndrome (IBS) is a common chronic gastrointestinal (GI) disorder that is characterized by a combination of abdominal pain or discomfort, bloating and alterations in bowel movements. This review presents recent developments concerning the roles of diet and GI endocrine cells in the pathophysiology of IBS and of individual dietary guidance in the management of IBS. Patients with IBS typically report that food aggravates their IBS symptoms. The interactions between specific types of foodstuffs rich in fermentable oligosaccharides, disaccharides, monosaccharides and polyols (FODMAPs) and GI endocrine cells induce changes in cell densities. Providing individual dietary guidance about a low FODMAP intake, high soluble-fiber intake, and changing the proportions of protein, fat and carbohydrates helps to reduce the symptoms experienced by patients with IBS and to improve their quality of life. These improvements are due to restoring the densities of the GI endocrine cells back to normal. The reported observations emphasize the role of GI endocrine cells in the pathophysiology of IBS and support the provision of dietary guidance as a first-line treatment for managing IBS.
\end{abstract}

\section{Contents}

1. Introduction

2. Diet

3. Gastrointestinal endocrine cells

4. Individual dietary guidance

5. Conclusion

Correspondence to: Dr Tarek Mazzawi, Division of Gastroenterology, Department of Clinical Medicine, University of Bergen, Jonas Lies vei 89, 5021 Bergen, Norway

E-mail: tarek.mazzawi@gmail.com

Key words: dietary guidance, enteroendocrine cells, fermentable oligosaccharides, disaccharides, monosaccharides and polyols, irritable bowel syndrome

\section{Introduction}

Irritable bowel syndrome (IBS). IBS is a common chronic disorder of the gastrointestinal (GI) tract (1-4) that seems to have multifactorial causes (2). It is more common in women than in men, and occurs more often under the age of 50 years (5-11). IBS is reportedly the most commonly diagnosed disorder of the GI in general practice (12), being an even more common reason for seeking medical care than diabetes, hypertension or asthma (13-15). Typically, 12-14\% of visits to general practitioners and $25-28 \%$ of referrals to gastroenterologist involve patients with IBS $(4,13,15,16)$.

The estimated prevalence of IBS ranges between 5 and $20 \%$ of the population worldwide $(1,2,4,6,8-10,17-22)$, with marked geographical variations (9). Using Rome II criteria, the prevalence is $11.5 \%$ in Europe (9), $12.1 \%$ in Canada (23), $4.7 \%$ in the USA (24), 6.9\% in Australia (25), 34\% in Egypt (26), 4\% in India $(27,28)$ and $4.6-5.6 \%$ in China (29). The prevalence of IBS in Scandinavian countries is as follows: $10.5 \%$ in Denmark (30), $14.5 \%$ in Sweden (31), $8 \%$ in the south of Norway (32) and 25\% in the north of Norway (33).

IBS is mainly diagnosed clinically based on the presenting symptoms due to the lack of biochemical, histopathological or radiological diagnostic tests $(3,4,34,35)$. The symptoms of IBS comprise abdominal pain or discomfort, abdominal bloating or distension and alterations in the stool $(1,4,34,36)$. Based on the predominant bowel movements, patients with IBS are classified into diarrhea-predominant (IBS-D), constipation-predominant (IBS-C) and mixed diarrhea and constipation $(37,38)$. Rome IV criteria are the currently used symptom-based diagnostic criteria (39).

It is known that IBS neither increases mortality (40) nor develops into serious diseases, such as cancer or inflammatory bowel disease $(41,42)$. However, the morbidity associated with IBS can be as serious as that for major chronic diseases, such as congestive heart failure (43), hepatic cirrhosis (44), renal insufficiency and diabetes (11), with considerable costs to society $(17,45-48)$. Patients with IBS tend to be less productive at work or school due to frequent absences $(6,13,36,49,50)$, changing or losing jobs and turning down promotions more 
frequently $(13,36)$. These patients have to pay high healthcare costs due to the need to undergo numerous diagnostic tests, frequent visits to the doctor, recurrent hospital admissions and the consumption of more medications than patients without IBS (36). IBS is therefore considered an economic burden for both the patients themselves and society as a whole $(2,17,43,45,51-53)$. The quality of life is lower for patients with IBS than for healthy subjects $(4,6,9,19-22,52)$ due to IBS negatively affecting several aspects of the life of patients, such as sleep, diet, work, leisure, travel, sexual activity and mood (depression or anxiety) (36).

Pathogenesis. Several factors seem to be involved in the pathogenesis of IBS, including hereditariness, diet, mucosal low-grade inflammation, GI microbiota and abnormal endocrine cells in the GI tract (Fig. 1) (4,35,54-78). This review discusses the effects of applying individual dietary guidance on symptoms, quality of life and GI endocrine cells in patients with IBS.

\section{Diet}

More than two-thirds of patients with IBS associate the development of their symptoms with the consumption of certain foodstuffs (71-73), such as milk and other dairy products, wheat products, caffeine, certain meats, cabbage, onion, peas, beans, tomatoes, hot spices and fried foods $(13,52,71,79)$, as well as raw vegetables, raw broccoli, paprika, leeks, garlic and mushrooms (52). These foodstuffs are rich in the poorly absorbed rapidly fermentable oligosaccharides, disaccharides, monosaccharides and polyols (FODMAPs) $(13,52,80-82)$. The time delay between the consumption of food until the appearance of IBS symptoms varies, with $28 \%$ of patients experiencing symptoms within $15 \mathrm{~min}$ of eating, and $93 \%$ reporting that the symptoms become more severe between $15 \mathrm{~min}$ and $3 \mathrm{~h}$ (71).

FODMAPs. Carbohydrates constitute the largest source of energy for humans, ranging from 40 to $80 \%$ of the total energy requirements (81). There are two types of dietary carbohydrates, namely long-chain carbohydrates (starch, resistant starch and non-starch polysaccharides) and shortchain (sugars, polyols and oligosaccharides) (80). Long-chain carbohydrates provide benefits of fecal bulking, accelerating colonic transit and causing slight acidification of the luminal milieu (80). On the other hand, short-chain carbohydrates, also referred to as prebiotics, stimulate the growth of beneficial bacteria in the colon (Bifidobacteria and Lactobacillus) and include fructans (fructo-oligosaccharides and inulin) and galacto-oligosaccharides $(80,83)$. Prebiotics help to reduce the risk of GI infections (84), improve laxation (85) and calcium absorption (86), preserve the GI mucosal barrier (87) and stimulate the immune system of the GI tract that may reduce the risk of colon cancer (demonstrated in animals) (88).

The microbiota in the colon ferments undigested long-chain carbohydrates and produces gases (carbon dioxide, hydrogen and/or methane) and short-chain fatty acids (butyrate, which is an important source of energy for colonocytes and the colonic microbiota) $(80,89-91)$. The poorly absorbed short-chain carbohydrates increase the volume of fluid in the bowel through osmosis $(80,91,92)$, which results in a natural

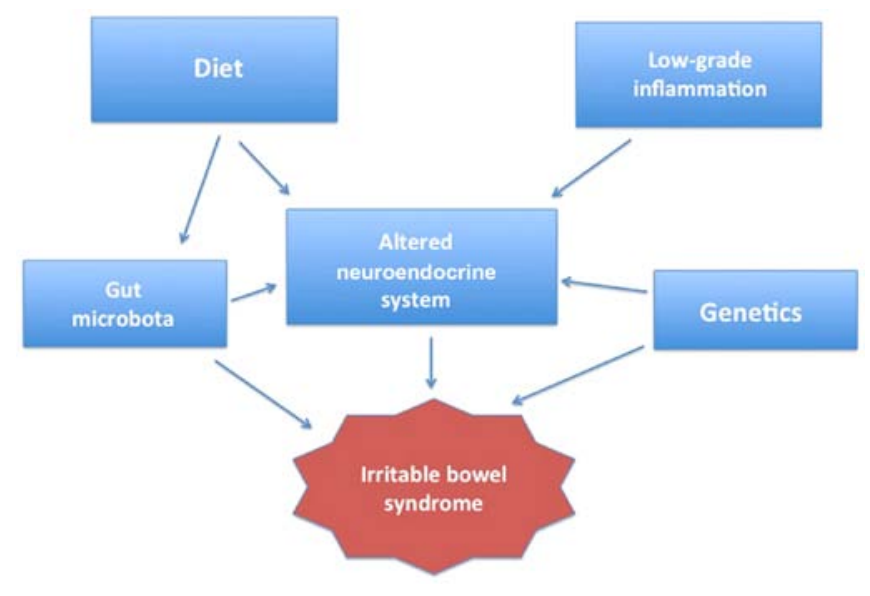

Figure 1. Factors considered to be involved in the pathogenesis of irritable bowel syndrome (IBS).

laxative effect in healthy individuals and diarrhea in patients with IBS (80). The gut microbiota in patients with IBS comprises fewer Lactobacillus and Bifidobacterium spp. and more Clostridium spp. that ferment FODMAPs and fiber and produce gas, leading to luminal distension with symptoms of abdominal pain and bloating (93-95).

The importance of both the presence of specific types of FODMAPs and the total content of FODMAPs in the diet should be noted $(75,80,81)$. Some foods contain several types of FODMAPs; for example, white onion contains excess fructose, raffinose, nystose and kestose, which are particularly problematic for patients with IBS (81). The main clinical problems associated with the total content of a major FODMAP are likely to be due to fructans in vegetables and, to a lesser extent, to free fructose and sorbitol in fruits (81).

Dietary fiber. Dietary fiber is defined as the sum of indigestible polysaccharides and lignin (96). The various types of fiber are categorized based on their holding capacity of water into water-soluble and water-insoluble. Water-soluble fiber (with a high water-holding capacity) such as pectin, gums and psyllium accounts for 4 to $21 \%$ of the dietary fiber in cereal bran and $19-59 \%$ of that in legumes, vegetables and fruits. Oat is the grain that is richest in water-soluble fiber. Water-insoluble fiber (with a low water-holding capacity) is found in wheat, rye, rice and most other grains. Legumes and beans contain both water-soluble and water-insoluble fiber (96).

It has been reported that foods containing a higher proportion of dietary fiber, particularly water-soluble fiber, can help to prevent diseases, such as coronary heart disease, diabetes, irritable bowel disease and colon cancer and obesity (96, and refs therein).

Fiber has been used as a bulking agent in the treatment of IBS $(74,96)$. Consuming water-soluble fiber tends to improve the symptoms of IBS compared to consuming water-insoluble fiber (74,97-99). Indeed, consuming water-insoluble fiber may actually worsen the symptoms of IBS $(74,97)$ by causing increased bloating and abdominal discomfort (100). Forexample, it is recommended for patients with IBS to consume psyllium (mostly water-soluble fiber) rather than bran (water-insoluble fiber) in order to alleviate their symptoms (100). 
Fat. The lipolysis of triglycerides comprising $>12$ carbon atoms is initiated in the stomach with the formation of emulsions of finely dispersed lipids that bind to gastric lipase. This process of fat digestion is completed in the duodenum by pancreatic lipase and releases fatty acids and monoglycerides. The lipid components (fatty acids and monoglycerides) then form water-soluble micelles with conjugated bile acids and are absorbed across the enterocyte membrane. The triglycerides are then reassembled and incorporated into chylomicrons and transported via the lymphatic system. On the other hand, medium-chain triglycerides (comprising 8-12 carbon atoms) are absorbed directly into the bloodstream without the need for luminal lipolysis and micelle formation. Under physiological conditions, no dietary fat enters the colon since fat is digested and completely absorbed in the small bowel.

Fat modulates the functions of the GI tract in healthy individuals (89). Different meals with different caloric contents activate several braking mechanisms in the GI tract at different rates (101-103). In healthy individuals, fat in the stomach slows gastric emptying, while in the duodenum it stimulates pyloric pressure $(89,102)$ and increases biliopancreatic secretion (104), thus activating the gastroduodenal brake $(89,105,106)$. When fat reaches the proximal small intestine, it promotes a jejunal brake to decrease biliopancreatic secretions $(103,104)$ and slow the intestinal transit (107). Finally, an ileal brake is activated upon the arrival of fat at the ileum (108), which allows more time for fat digestion and absorption and thereby prevents it being lost into the colon (107). The jejunal and ileal brakes are mediated by different GI hormones (107,108).

Patients with IBS have abnormal lipid-dependent motor dysfunction that affects the small intestine, but not the colon (109). These patients also exhibit increased small intestine sensitivity to lipid exposure, which induces symptoms of bloating $(89,109)$, fullness and nausea at lower nutrient loads, and enhances GI sensitivity to mechanical distension (89). In addition, intraluminal fat in the small intestine of patients with IBS impairs gas transit and results in the development of gas retention (bloating) and abdominal distension, particularly in the jejunum (109). Lipids also exacerbate rectal hypersensitivity $(89,110)$ and increase the perception of rectal distension in patients with IBS $(89,111)$, causing pain in patients with IBS-C patients, but urgency in patients with IBS-D (89).

Some patients with IBS reportedly relate the development of their symptoms to the consumption of fat-rich meals. However, no consistent differences in dietary fat consumption have been observed between patients with IBS and healthy controls $(52,89)$.

Protein. Almost $20 \%$ of the dietary protein enters the distal colon and undergoes putrefaction by colonic bacteria to produce ammonia, amines, phenols and sulfides $(112,113)$. Ammonia is essential for bacterial metabolism and protein synthesis. Branched-chain fatty acids (isovalerate and isobutyrate) $(113,114)$ and short-chain fatty acids (butyrate) $(113,115)$ are produced in the distal part of the colon in the absence of carbohydrate fermentation (which occurs at the proximal colon) (113). Another product of protein putrefaction is sulfurcontaining gas (hydrogen sulfide), which has a foul odor (112). The products of protein putrefaction are potentially harmful, phenols are carcinogenic in other systems and hydrogen sulfide is toxic to the epithelium. However, only the malodorous flatus is of concern to patients with IBS, and no definitive effects of malabsorbed protein on intestine motility or visceral hypersensitivity have been identified (112).

Gluten is a mixture of two proteins (gliadin and glutenin) that is found in wheat, barley and rye (112). Consuming gluten activates the immune system so as to change the function of the mucosal barrier that increases intestinal permeability, a condition known as celiac disease that presents with symptoms mimicking IBS. A gluten-free diet usually reduces bowel frequency in patients with IBS-D who are positive for human leukocyte antigen (HLA)-DQ2/8 due to the reduction in intestinal permeability (116). In addition, a gluten-free diet improves the symptoms of IBS due to the associated reduced intake of FODMAPs in wheat rather than of gluten in foods with gluten as a common component (117).

Food chemicals. Natural chemicals, such as amines, glutamates and salicylates occur in foods. Salicylates are found in plants whereas amines and glutamates are products of protein breakdown in animal meat (118). Food additives, such as glutamates are used as flavor enhancers and benzoates, sulfites, and nitrates are used as preservatives (118). These bioactive chemicals interact with the GI luminal chemoreceptors and influence the function of the enteric nervous system of the GI tract (112). A diet that is low in these chemicals may be beneficial to patients with IBS, whereas there is no evidence of the benefits of reducing caffeine or ethanol consumption (112).

\section{Gastrointestinal endocrine cells}

General. The GI endocrine cells are scattered among the epithelial cells lining the GI lumen $(61,119-121)$. They comprise almost $1 \%$ of all epithelial cells in the GI tract and are considered to be the largest endocrine organ in the body (121-123). All epithelial cell types in the GI tract (including GI endocrine cells) originate from pluripotent stem cells with an endodermal origin (124-133). Gastrointestinal stem cells differentiate into endocrine cells over a period of 2-6 days $(134,135)$. The GI endocrine cells project specialized microvilli into the GI lumen to sense the luminal contents (mainly nutrients) and release specific hormones into the lamina propria $(61,119,120,136-145)$.

There are at least 15 different types of GI endocrine cells in the GI tract releasing different types of hormones $(2,127)$. The types of released hormones depend on the types of sensed nutrients: protein and fat trigger the release of serotonin; somatostatin, ghrelin, polypeptide YY (PYY) and carbohydrates suppress ghrelin release; and carbohydrates and fat trigger the release of oxyntomodulin (enteroglucagon) $(2,93,146)$. Particular GI endocrine cells are located either in specific parts of the GI tract or throughout the GI tract $(93,127,146,147)$. Cells producing gastrin and ghrelin are found in the stomach, those producing secretin, cholecystokinin and gastric inhibitory peptide are found in the duodenum, those producing oxyntomodulin (enteroglucagon) and PYY are located in the lower small and large intestines, and those producing serotonin and somatostatin are found throughout the GI tract $(93,127,146,147)$. The functions of the different hormones are summarized in Table I (2). 
Table I. Functions of the hormones of the gastrointestinal endocrine cells.

\begin{tabular}{ll} 
Hormones & \multicolumn{1}{c}{ Function } \\
\hline Gastrin & $\begin{array}{l}\text { Stimulates gastric acid secretion and histamine release; trophic action on gastric } \\
\text { mucosa and stimulates contraction of lower esophageal sphincter and antrum } \\
\text { Increases appetite and feeding; stimulates gastric and intestinal motility }\end{array}$ \\
Shrelin & $\begin{array}{l}\text { Stimulates pancreatic bicarbonate and fluid secretion; inhibits gastric emptying; } \\
\text { and inhibits contractile activity of small and large intestine }\end{array}$ \\
CKK & $\begin{array}{l}\text { Inhibits gastric emptying; stimulates gall bladder contraction, intestinal motility } \\
\text { and pancreatic exocrine secretion; stimulates growth; and regulates food intake }\end{array}$ \\
GIP & Belongs to incretins. Inhibits gastric acid secretion \\
Oxyntomodulin (enteroglucagon) & Inhibits gastric and pancreatic secretions \\
PYY & Major 'ileal brake' mediator. Delays gastric emptying; inhibits gastric and pancreatic \\
Serotonin & secretion. Anti-diarrheal effect by stimulating the absorption of water and electrolytes \\
Somatostatin & Inhibits intestinal contraction, gut exocrine and neuroendocrine secretions
\end{tabular}

CKK, cholecystokinin; GIP, gastric inhibitory peptide; PYY, peptide YY.

Several functions of the GI tract, such as motility, secretion, absorption, microcirculation, local immune defense, cell proliferation and food intake, are regulated by the interactions of GI endocrine cells with themselves and with the enteric nervous system, independent of the central nervous system but also communicating and integrated with it $(2,119,146,148-151)$. The GI endocrine cells release their hormones that exert their effects via endocrine signaling (through the bloodstream to distant targets), paracrine or autocrine signaling (locally), synaptic signaling or neuroendocrinally (being released from synapses into the bloodstream) $(2,93,146,148)$.

GI endocrine cells in IBS. There is increasing evidence of an altered neuroendocrine system, namely the GI endocrine cells, being a cause of IBS, since the densities of different types of GI endocrine cells in the different parts of the GI tract are abnormal in patients with IBS $(4,35,61-70)$. Such alterations are responsible for abnormal functions of the GI tract, such as visceral hypersensitivity, dysmotility and abnormal secretion, all of which are characteristics of IBS (35).

\section{Individual dietary guidance}

Several studies have shown that a low-FODMAP diet can improve the symptoms experienced by patients with IBS $(78,90,91,152-157)$ and that these patients tend to comply with consuming such a diet; one study found that $>75 \%$ of patients were compliant (75). However, consuming such a diet over a long period of time is associated with several complications, such as a lack of nutrients (52), and changes in the fecal microbiota $(158,159)$. Many patients with IBS make a conscious choice to avoid certain foodstuffs, some of which belong to the FODMAPs group. However, they also tend to "unknowingly' consume other foodstuffs that are rich in FODMAPs and avoid food sources that are important to their health (52). A Norwegian study on food intolerance and IBS found that
$62 \%$ of the included subjects limited or excluded some foodstuffs from their daily meals, while $12 \%$ made drastic changes in their diet that could result in nutritional deficiencies in the long term (72). Patients with IBS tend to have low intakes of calcium, potassium, magnesium, vitamin $A$, vitamin $B_{12}$ and vitamin $B_{2}(52,160-162)$. Avoiding such adverse effects of the long-term consumption of a low-FODMAP diet therefore requires the administration of dietary guidance (75).

Administering individual dietary guidance. Educating patients can facilitate changes in their behavior for the purpose of disease management and prevention (163). Patients with IBS are particularly interested in learning about dietary modifications, coping strategies and the causes of the disease (163). Dietary guidance can be administered individually, whereby patients are provided with information via one-to-one consultations; this approach is useful due to the tolerance to different FODMAPs, varying widely between individual patients (164). When being provided with individual dietary guidance, patients are scheduled to attend several relatively short sessions, administered by a physician, nurse or nutritionist, to receive information concerning IBS and the appropriate foodstuffs they should consume to reduce their symptoms. The main emphasis should be on consuming foodstuffs that are low in FODMAPs and water-insoluble fiber, and changing the proportions of protein (increase), fat (decrease) and carbohydrates (decrease). Providing several sessions of consultation gives the patients reassurance and confidence while they are receiving dietary guidance. Using a daily diary to register the daily consumption of food and fluids and the accompanying IBS symptoms (if any) helps in identifying which foodstuffs worsen the symptoms experienced by the patients $(52,165,166)$.

Effect of individual dietary guidance on symptoms and quality of life of patients with IBS. Individual dietary guidance helps patients with IBS to choose dietary items that are low in 


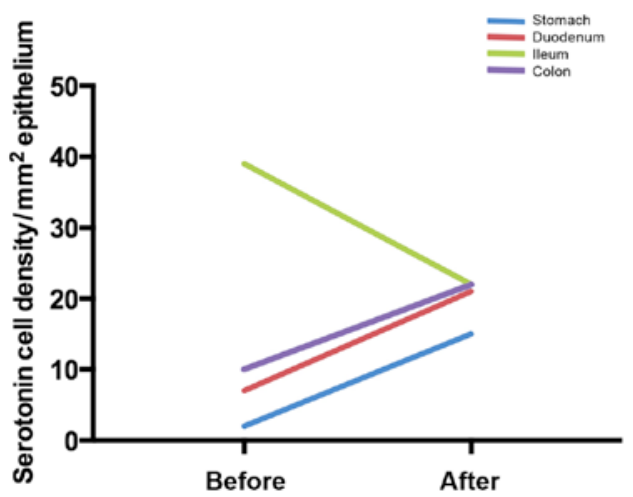

Figure 2. Mean serotonin cell densities in different parts of the gastrointestinal (GI) tract in patients with irritable bowel syndrome (IBS) before and after receiving dietary guidance.
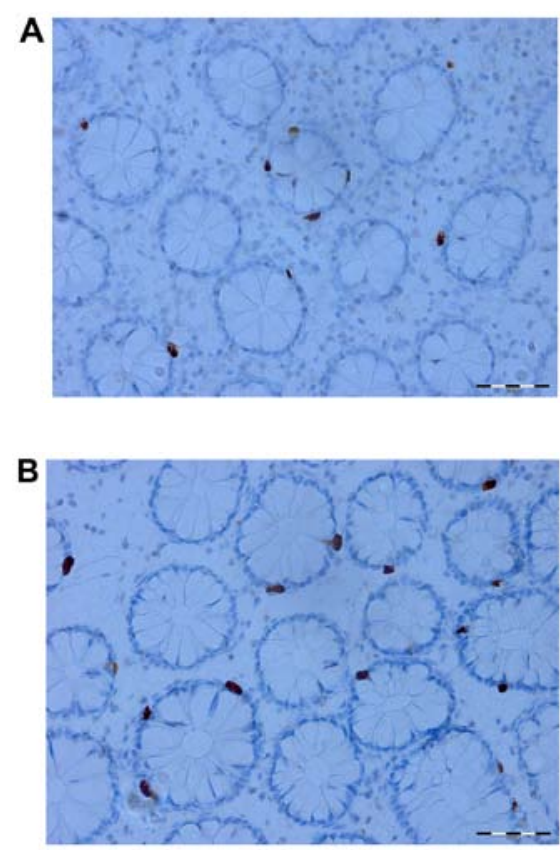

Figure 3. Serotonin cells in the colon of an irritable bowel syndrome (IBS) patient before (A) and after $(\mathrm{B})$ receiving dietary guidance.

FODMAPs and water-insoluble fiber (166). The effects of this approach on symptoms and the quality of life of patients with IBS have been assessed using several questionnaires, such as the Birmingham IBS Symptom Questionnaire, the Irritable Bowel Syndrome - Quality of Life (IBS-QOL) questionnaire, and the Short-Form Nepean and Dyspepsia Index (SF-NDI) quality-of-life questionnaire $(52,166)$. The Birmingham IBS symptom questionnaire is disease-specific and measures the symptoms experienced by IBS patients, namely pain, diarrhea and constipation (167). IBS symptoms, as assessed by the Birmingham IBS symptom questionnaire, improve significantly after receiving dietary guidance, particularly the symptoms of pain $(52,166)$ and diarrhea $(166)$, but not constipation $(52,166)$.

The IBS-QOL questionnaire is IBS-specific and assesses physical and psychosocial functioning as a result of IBS $(168,169)$. The SF-NDI questionnaire is a disease-specific questionnaire that assesses the health-related quality of life and was constructed and validated primarily in patients with

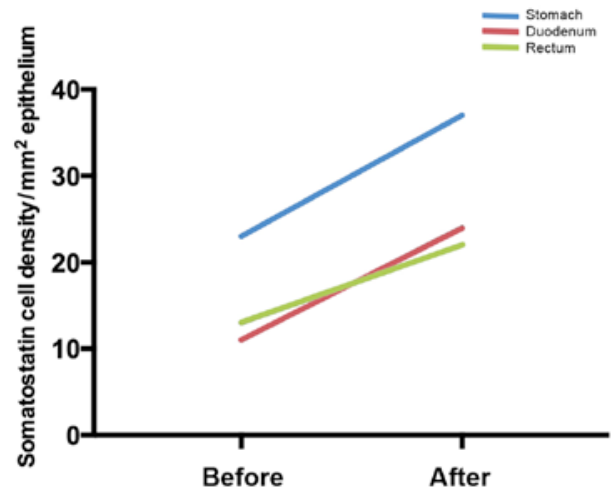

Figure 4. Mean somatostatin cell densities in different parts of the gastrointestinal (GI) tract in patients with irritable bowel syndrome (IBS) before and after receiving dietary guidance.

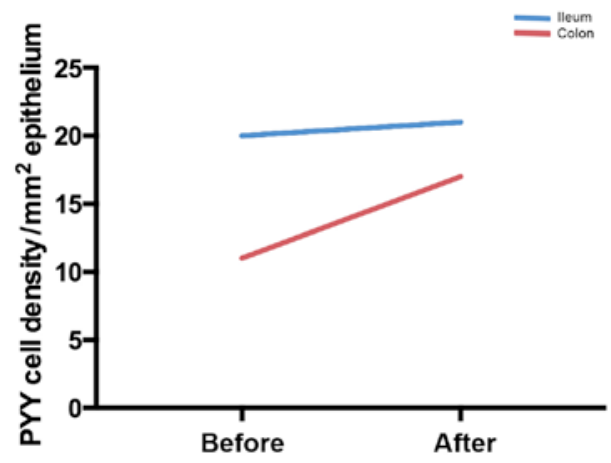

Figure 5. Mean peptide YY (PYY) cell densities in the ileum and colon of patients with irritable bowel syndrome (IBS) before and after receiving dietary guidance.

dyspepsia (170). However, a validated version of the questionnaire translated into Norwegian was demonstrated to perform well in patients with IBS (171). The total scores, as assessed by the IBS-QOL and SF-NDI questionnaires, showed significant improvements in the quality of life of patients with IBS after they received dietary guidance $(52,166)$.

Individual dietary guidance helps to reduce IBS symptoms, improving the quality of life of patients with IBS $(52,165,166)$, and ensures that they have an adequate intake of necessary vitamins and minerals, thus avoiding multiple nutrition deficiencies $(52,166)$.

Effects of individual dietary guidance on GI endocrine cells. At the cellular level, changing the diet through individual dietary guidance changes the densities of different GI endocrine cells in different parts of the GI tract (172-175), as shown in Figs. 2-5. Chromogranin A $(\mathrm{CgA})$ is considered to be a general marker of endocrine cells (176-178). As previously demonstrated, the densities of $\mathrm{CgA}$-immunoreactive cells are abnormal in the stomach, duodenum, ileum and colon of patients with IBS, and dietary guidance tends to change these densities toward the values measured in healthy control subjects $(173,179,180)$. These changes are considered to be brought about by changes in different endocrine cells in the respective parts of the GI tract after providing dietary guidance. For example, in the stomach, the densities of several endocrine cells (gastrin, 
ghrelin, serotonin and somatostatin) changed toward the values measured in healthy control subjects after providing dietary guidance, but only somatostatin cell density showed a significant change in the gastric corpus (181). The densities of serotonin cells in the duodenum and ileum changed significantly $(172,175)$, and the density of somatostatin cells in the duodenum changed significantly after providing dietary guidance toward that measured in healthy control subjects (175). After providing dietary guidance, the densities of serotonin and PYY cells tend to normalize in different segments of the colon, with the density of somatostatin cells increasing in the rectum (174).

The observation that dietary guidance can alter the densities of several GI endocrine cells in patients with IBS, particularly serotonin, PYY and somatostatin cells, to approach those in healthy control subjects suggests that these changes underlie the reduction in pain and the improvement in diarrhea as quantified using the Birmingham IBS symptom questionnaire, and consequently the improvement in the quality of life of these patients.

\section{Conclusion}

Patients with IBS typically report that food aggravates their IBS symptoms. The interactions between specific types of foodstuffs and GI endocrine cells result in changes in these cell densities. Providing individual dietary guidance about a low FODMAP intake, high soluble-fiber intake, and changing the proportions of protein, fat and carbohydrates helps to reduce the symptoms experienced by IBS patients and to improve their quality of life. This improvement is accompanied by changes in the densities of the GI endocrine cells where some densities are restored back to the normal values. These observations emphasize on the role of GI endocrine cells in the pathophysiology of IBS, and support the provision of dietary guidance as a firstline treatment for managing IBS (76).

\section{Acknowledgements}

The studies conducted by the authors and cited in this review were supported by grants from Helse-Vest (grant no. 911976) and Helse-Fonna (grant no. 40415).

\section{References}

1. Thompson WG: A world view of IBS. In: Irritable Bowe Syndrome: Diagnosis and Treatment. Camilleri $M$ and Spiller RC (eds). WB Saunders, Edinburgh, pp17-26, 2002.

2. El-Salhy M, Gundersen D, Hatlebakk JG and Hausken T (eds): Irritable Bowel Syndrome. Nova Science Publishers, New York, NY, 2012.

3. Camilleri M, Heading RC and Thompson WG: Clinical perspectives, mechanisms, diagnosis and management of irritable bowel syndrome. Aliment Pharmacol Ther 16: 1407-1430, 2002.

4. El-Salhy M: Irritable bowel syndrome: diagnosis and pathogenesis. World J Gastroenterol 18: 5151-5163, 2012.

5. Kay L, Jørgensen T and Jensen KH: The epidemiology of irritable bowel syndrome in a random population: prevalence, incidence, natural history and risk factors. J Intern Med 236: 23-30, 1994

6. Drossman DA, Li Z, Andruzzi E, Temple RD, Talley NJ, Thompson WG, Whitehead WE, Janssens J, Funch-Jensen P, Corazziari E, et al: U.S. householder survey of functional gastrointestinal disorders. Prevalence, sociodemography, and health impact. Dig Dis Sci 38: 1569-1580, 1993.
7. Kennedy TM, Jones RH, Hungin AP, O'flanagan $\mathrm{H}$ and Kelly P: Irritable bowel syndrome, gastro-oesophageal reflux, and bronchial hyper-responsiveness in the general population. Gut 43 . 770-774, 1998.

8. Everhart JE and Renault PF: Irritable bowel syndrome in office-based practice in the United States. Gastroenterology 100: 998-1005, 1991.

9. Hungin AP, Whorwell PJ, Tack J and Mearin F: The prevalence, patterns and impact of irritable bowel syndrome: an international survey of 40,000 subjects. Aliment Pharmacol Ther 17: 643-650, 2003

10. O'Keefe EA, Talley NJ, Zinsmeister AR and Jacobsen SJ: Bowel disorders impair functional status and quality of life in the elderly: a population-based study. J Gerontol A Biol Sci Med Sci 50: M184-M189, 1995.

11. Gralnek IM, Hays RD, Kilbourne AM, Chang L and Mayer EA: Racial differences in the impact of irritable bowel syndrome on health-related quality of life. J Clin Gastroenterol 38: 782-789, 2004.

12. Thompson WG, Heaton KW, Smyth GT and Smyth C: Irritable bowel syndrome in general practice: prevalence, characteristics, and referral. Gut 46: 78-82, 2000.

13. El-Salhy M, Ostgaard H, Gundersen D, Hatlebakk JG and Hausken T: The role of diet in the pathogenesis and management of irritable bowel syndrome (Review). Int J Mol Med 29: 723-731, 2012.

14. Mitchell CM and Drossman DA: Survey of the AGA membership relating to patients with functional gastrointestinal disorders. Gastroenterology 92: 1282-1284, 1987.

15. Schuster MM: Defining and diagnosing irritable bowel syndrome. Am J Manag Care 7 (Suppl 8): S246-S251, 2001.

16. El-Salhy M,Hatlebakk JG, Gilja OH and Hausken T: Irritable bowel syndrome: recent developments in diagnosis, pathophysiology, and treatment. Expert Rev Gastroenterol Hepatol 8: 435-443, 2014.

17. Talley NJ, Gabriel SE, Harmsen WS, Zinsmeister AR and Evans RW: Medical costs in community subjects with irritable bowel syndrome. Gastroenterology 109: 1736-1741, 1995.

18. Thompson WG and Heaton KW: Functional bowel disorders in apparently healthy people. Gastroenterology 79: 283-288, 1980.

19. Bordie AK: Functional disorders of the colon. J Indian Med Assoc 58: 451-456, 1972.

20. Jones R and Lydeard S: Irritable bowel syndrome in the general population. BMJ 304: 87-90, 1992.

21. Harvey RF, Salih SY and Read AE: Organic and functional disorders in 2000 gastroenterology outpatients. Lancet 1: 632-634, 1983.

22. Wilson S, Roberts L, Roalfe A, Bridge P and Singh S: Prevalence of irritable bowel syndrome: a community survey. Br J Gen Pract 54: 495-502, 2004.

23. Thompson WG, Irvine EJ, Pare P, Ferrazzi S and Rance L: Functional gastrointestinal disorders in Canada: first population-based survey using Rome II criteria with suggestions for improving the questionnaire. Dig Dis Sci 47: 225-235, 2002.

24. Saito YA, Locke GR, Talley NJ, Zinsmeister AR, Fett SL and Melton LJ III: A comparison of the Rome and Manning criteria for case identification in epidemiological investigations of irritable bowel syndrome. Am J Gastroenterol 95: 2816-2824, 2000.

25. Boyce PM, Koloski NA and Talley NJ: Irritable bowel syndrome according to varying diagnostic criteria: are the new Rome II criteria unnecessarily restrictive for research and practice? Am J Gastroenterol 95: 3176-3183, 2000.

26. Abdulmajeed A, Rabab MA, Sliem HA and Hebatallah NE: Pattern of irritable bowel syndrome and its impact on quality of life in primary health care center attendees, Suez governorate, Egypt. Pan Afr Med J 9: 5, 2011.

27. Ghoshal UC, Abraham P, Bhatt C, Choudhuri G, Bhatia SJ, Shenoy KT, Banka NH, Bose K, Bohidar NP, Chakravartty K, et al: Epidemiological and clinical profile of irritable bowel syndrome in India: report of the Indian Society of Gastroenterology Task Force. Indian J Gastroenterol 27: 22-28, 2008.

28. Makharia GK, Verma AK, Amarchand R, Goswami A, Singh P, Agnihotri A, Suhail F and Krishnan A: Prevalence of irritable bowel syndrome: a community based study from northern India. J Neurogastroenterol Motil 17: 82-87, 2011.

29. Liu J and Hou X: A review of the irritable bowel syndrome investigation on epidemiology, pathogenesis and pathophysiology in China. J Gastroenterol Hepatol 26 (Suppl 3): 88-93, 2011.

30. Rasmussen S, Jensen TH, Henriksen SL, Haastrup PF, Larsen PV, Søndergaard J and Jarbøl DE: Overlap of symptoms of gastroesophageal reflux disease, dyspepsia and irritable bowel syndrome in the general population. Scand J Gastroenterol 50: 162-169, 2015. 
31. Kjellström L, Molinder H, Agréus L, Nyhlin H, Talley NJ and Andreasson A: A randomly selected population sample undergoing colonoscopy: prevalence of the irritable bowel syndrome and the impact of selection factors. Eur J Gastroenterol Hepatol 26: 268-275, 2014.

32. Vandvik PO, Lydersen S and Farup PG: Prevalence, comorbidity and impact of irritable bowel syndrome in Norway. Scand $\mathbf{J}$ Gastroenterol 41: 650-656, 2006.

33. Breckan RK, Asfeldt AM, Straume B, Florholmen J and Paulssen EJ: Prevalence, comorbidity, and risk factors for functional bowel symptoms: a population-based survey in Northern Norway. Scand J Gastroenterol 47: 1274-1282, 2012.

34. Longstreth GF, Thompson WG, Chey WD, Houghton LA, Mearin F and Spiller RC: Functional bowel disorders. Gastroenterology 130: 1480-1491, 2006.

35. El-Salhy M, Gundersen D, Gilja OH, Hatlebakk JG and Hausken T: Is irritable bowel syndrome an organic disorder? World J Gastroenterol 20: 384-400, 2014.

36. Hahn BA, Yan S and Strassels S: Impact of irritable bowel syndrome on quality of life and resource use in the United States and United Kingdom. Digestion 60: 77-81, 1999.

37. Spiller R, Aziz Q, Creed F, Emmanuel A, Houghton L, Hungin P, Jones R, Kumar D, Rubin G, Trudgill N, et al; Clinical Services Committee of The British Society of Gastroenterology: Guidelines on the irritable bowel syndrome: mechanisms and practical management. Gut 56: 1770-1798, 2007.

38. Tillisch K, Labus JS, Naliboff BD, Bolus R, Shetzline M, Mayer EA and Chang L: Characterization of the alternating bowel habit subtype in patients with irritable bowel syndrome. Am J Gastroenterol 100: 896-904, 2005.

39. Drossman DA: Functional gastrointestinal disorders: history, pathophysiology, clinical features and RomeIV.Gastroenterology: Feb 19, 2016 (Epub ahead of print).

40. Harvey RF, Mauad EC and Brown AM: Prognosis in the irritable bowel syndrome: a 5-year prospective study. Lancet 1: 963-965, 1987.

41. García Rodríguez LA, Ruigómez A, Wallander MA, Johansson S and Olbe L: Detection of colorectal tumor and inflammatory bowel disease during follow-up of patients with initial diagnosis of irritable bowel syndrome. Scand J Gastroenterol 35: 306-311, 2000.

42. Nørgaard M, Farkas DK, Pedersen L, Erichsen R, de la Cour ZD, Gregersen H and Sørensen HT: Irritable bowel syndrome and risk of colorectal cancer: a Danish nationwide cohort study. Br J Cancer 104: 1202-1206, 2011.

43. Whitehead WE, Burnett CK, Cook EW III and Taub E: Impact of irritable bowel syndrome on quality of life. Dig Dis Sci 41: 2248-2253, 1996.

44. Schmulson MRG and Kershenobich D: Los pacientes con trastornos funcionales digestivos (TFD) tienen majo compromiso de la calidad de vida (CV) evaluadas por el SF-36 comparados con pacientes con hepatitis $\mathrm{C}$ y pancreatitis cronica. Rev Gastroenterol Mex 65 (Suppl): 50-51, 2000 (In Spanish)

45. Martin R, Barron JJ and Zacker C: Irritable bowel syndrome: toward a cost-effective management approach. Am J Manag Care 7 (Suppl 8): S268-S275, 2001.

46. Spiegel BM: The burden of IBS: looking at metrics. Curr Gastroenterol Rep 11: 265-269, 2009.

47. American Gastroenterological Association: The burden of gastrointestinal diseases. Bethesda, MD, 2001

48. Sandler RS, Everhart JE, Donowitz M, Adams E, Cronin K, Goodman C, Gemmen E, Shah S, Avdic A and Rubin R: The burden of selected digestive diseases in the United States. Gastroenterology 122: 1500-1511, 2002.

49. Li FX, Patten SB, Hilsden RJ and Sutherland LR: Irritable bowel syndrome and health-related quality of life: a population-based study in Calgary, Alberta. Can J Gastroenterol 17: 259-263, 2003

50. Thompson WG, Longstreth GF, Drossman DA, Heaton KW Irvine EJ and Müller-Lissner SA: Functional bowel disorders and functional abdominal pain. Gut 45 (Suppl 2): II43-II47, 1999.

51. Spanier JA, Howden CW and Jones MP: A systematic review of alternative therapies in the irritable bowel syndrome. Arch Intern Med 163: 265-274, 2003.

52. Ostgaard H, Hausken T, Gundersen D and El-Salhy M: Diet and effects of diet management on quality of life and symptoms in patients with irritable bowel syndrome. Mol Med Rep 5: 1382-1390, 2012.

53. Canavan C, West $\mathrm{J}$ and Card T: Review article: the economic impact of the irritable bowel syndrome. Aliment Pharmacol Ther 40: 1023-1034, 2014.
54. Saito YA: The role of genetics in IBS. Gastroenterol Clin North Am 40: 45-67, 2011.

55. Lee YJ and Park KS: Irritable bowel syndrome: emerging paradigm in pathophysiology. World J Gastroenterol 20: 2456-2469, 2014.

56. Grover M, Camilleri M, Smith K, Linden DR and Farrugia G: On the fiftieth anniversary. Postinfectious irritable bowel syndrome: mechanisms related to pathogens. Neurogastroenterol Motil 26: 156-167, 2014.

57. Ishihara S, Tada Y, Fukuba N, Oka A, Kusunoki R, Mishima Y, Oshima N, Moriyama I, Yuki T, Kawashima K, et al: Pathogenesis of irritable bowel syndrome - review regarding associated infection and immune activation. Digestion 87: 204-211, 2013.

58. Lin HC: Small intestinal bacterial overgrowth: a framework for understanding irritable bowel syndrome. JAMA 292: 852-858, 2004.

59. Hong SN and Rhee PL: Unraveling the ties between irritable bowel syndrome and intestinal microbiota. World J Gastroenterol 20: 2470-2481, 2014.

60. Balsari A, Ceccarelli A, Dubini F, Fesce E and Poli G: The fecal microbial population in the irritable bowel syndrome. Microbiologica 5: 185-194, 1982.

61. El-Salhy M: Ghrelin in gastrointestinal diseases and disorders: a possible role in the pathophysiology and clinical implications (Review). Int J Mol Med 24: 727-732, 2009.

62. El-Salhy M, Gilja OH, Gundersen D, Hatlebakk JG and Hausken T: Endocrine cells in the ileum of patients with irritable bowel syndrome. World J Gastroenterol 20: 2383-2391, 2014.

63. El-Salhy M, Gundersen D, Hatlebakk JG, Gilja OH and Hausken T: Abnormal rectal endocrine cells in patients with irritable bowel syndrome. Regul Pept 188: 60-65, 2014.

64. El-Salhy M, Gundersen D, Hatlebakk JG and Hausken T: Low-grade inflammation in the rectum of patients with sporadic irritable bowel syndrome. Mol Med Rep 7: 1081-1085, 2013.

65. El-Salhy M, Gundersen D, Ostgaard H, Lomholt-Beck B, Hatlebakk JG and Hausken T: Low densities of serotonin and peptide YY cells in the colon of patients with irritable bowel syndrome. Dig Dis Sci 57: 873-878, 2012.

66. El-Salhy M, Lomholt-Beck B and Hausken T: Chromogranin A as a possible tool in the diagnosis of irritable bowel syndrome. Scand J Gastroenterol 45: 1435-1439, 2010.

67. El-Salhy M, Mazzawi T, Gundersen D and Hausken T: Chromogranin A cell density in the rectum of patients with irritable bowel syndrome. Mol Med Rep 6: 1223-1225, 2012.

68. El-Salhy M and Rauma J: Low density of ghrelin cells in the oxyntic mucosa correlated to slow gastric emptying in patients with type 1 diabetes. Mol Med Rep 2: 893-896, 2009.

69. El-Salhy M, Vaali K, Dizdar V and Hausken T: Abnormal small-intestinal endocrine cells in patients with irritable bowel syndrome. Dig Dis Sci 55: 3508-3513, 2010.

70. El-Salhy M, Wendelbo IH and Gundersen D: Reduced chromogranin A cell density in the ileum of patients with irritable bowel syndrome. Mol Med Rep 7: 1241-1244, 2013.

71. Simrén M, Månsson A, Langkilde AM, Svedlund J, Abrahamsson H, Bengtsson U and Björnsson ES: Food-related gastrointestinal symptoms in the irritable bowel syndrome. Digestion 63: 108-115, 2001

72. Monsbakken KW, Vandvik PO and Farup PG: Perceived food intolerance in subjects with irritable bowel syndrome - etiology, prevalence and consequences. Eur J Clin Nutr 60: 667-672, 2006.

73. Dainese R, Galliani EA, De Lazzari F, Di Leo V and Naccarato R Discrepancies between reported food intolerance and sensitization test findings in irritable bowel syndrome patients. Am J Gastroenterol 94: 1892-1897, 1999.

74. Heizer WD, Southern S and McGovern S: The role of diet in symptoms of irritable bowel syndrome in adults: a narrative review. J Am Diet Assoc 109: 1204-1214, 2009.

75. Gibson PR and Shepherd SJ: Evidence-based dietary management of functional gastrointestinal symptoms: the FODMAP approach. J Gastroenterol Hepatol 25: 252-258, 2010.

76. Gibson PR: Food intolerance in functional bowel disorders. J Gastroenterol Hepatol 26 (Suppl 3): 128-131, 2011.

77. Barrett JS and Gibson PR: Fermentable oligosaccharides, disaccharides, monosaccharides and polyols (FODMAPs) and nonallergic food intolerance: FODMAPs or food chemicals? Therap Adv Gastroenterol 5: 261-268, 2012.

78. de Roest RH, Dobbs BR, Chapman BA, Batman B, O'Brien LA, Leeper JA, Hebblethwaite CR and Gearry RB: The low FODMAP diet improves gastrointestinal symptoms in patients with irritable bowel syndrome: a prospective study. Int J Clin Pract 67: 895-903, 2013. 
79. Nanda R, James R, Smith H, Dudley CR and Jewell DP Food intolerance and the irritable bowel syndrome. Gut 30 : 1099-1104, 1989.

80. Biesiekierski JR, Rosella O, Rose R, Liels K, Barrett JS, Shepherd SJ, Gibson PR and Muir JG: Quantification of fructans, galacto-oligosacharides and other short-chain carbohydrates in processed grains and cereals. J Hum Nutr Diet 24: 154-176, 2011

81. Muir JG, Rose R, Rosella O, Liels K, Barrett JS, Shepherd SJ and Gibson PR: Measurement of short-chain carbohydrates in common Australian vegetables and fruits by high-performance liquid chromatography (HPLC). J Agric Food Chem 57: 554-565, 2009.

82. Muir JG, Shepherd SJ, Rosella O, Rose R, Barrett JS and Gibson PR: Fructan and free fructose content of common Australian vegetables and fruit. J Agric Food Chem 55: 6619-6627, 2007.

83. Gibson GR, Probert HM,Loo JV, Rastall RA and Roberfroid MB: Dietary modulation of the human colonic microbiota: updating the concept of prebiotics. Nutr Res Rev 17: 259-275, 2004.

84.Gibson GR, McCartney AL and Rastall RA: Prebiotics and resistance to gastrointestinal infections. Br J Nutr 93(Suppl 1): $31-34,2005$

85. Szajewska H, Ruszczyński M and Radzikowski A: Probiotics in the prevention of antibiotic-associated diarrhea in children a meta-analysis of randomized controlled trials. J Pediatr 149 367-372, 2006.

86. Cashman, K: Prebiotics and calcium bioavailability. Curr Issues Intest Microbiol 4: 21-32, 2003.

87. Kleessen B and Blaut M: Modulation of gut mucosal biofilms. Br J Nutr 93 (Suppl 1): 35-40, 2005.

88. Rafter J, Bennett M, Caderni G, Clune Y,Hughes R, Karlsson PC Klinder A, O'Riordan M, O'Sullivan GC, Pool-Zobel B, et al Dietary synbiotics reduce cancer risk factors in polypectomized and colon cancer patients. Am J Clin Nutr 85: 488-96, 2007.

89. Feinle-Bisset C and Azpiroz F: Dietary lipids and functional gastrointestinal disorders. Am J Gastroenterol 108 737-747, 2013

90. Ong DK, Mitchell SB, Barrett JS, Shepherd SJ, Irving PM, Biesiekierski JR, Smith S, Gibson PR and Muir JG: Manipulation of dietary short chain carbohydrates alters the pattern of gas production and genesis of symptoms in irritable bowel syndrome. J Gastroenterol Hepatol 25: 1366-1373, 2010.

91. Shepherd SJ and Gibson PR: Fructose malabsorption and symptoms of irritable bowel syndrome: guidelines for effective dietary management. J Am Diet Assoc 106: 1631-1639, 2006.

92. Barrett JS, Gearry RB, Muir JG, Irving PM, Rose R, Rosella O, Haines ML, Shepherd SJ and Gibson PR: Dietary poorly absorbed, short-chain carbohydrates increase delivery of water and fermentable substrates to the proximal colon. Aliment Pharmacol Ther 31: 874-882, 2010.

93.El-Salhy M, Gilja OH, Gundersen D, Hatlebakk JG and Hausken T: Interaction between ingested nutrients and gut endocrine cells in patients with irritable bowel syndrome (Review). Int J Mol Med 34: 363-371, 2014.

94. Kassinen A, Krogius-Kurikka L, Mäkivuokko H, Rinttilä T, Paulin L, Corander J, Malinen E, Apajalahti J and Palva A: The fecal microbiota of irritable bowel syndrome patients differs significantly from that of healthy subjects. Gastroenterology 133 24-33, 2007

95. Si JM, Yu YC, Fan YJ and Chen SJ: Intestinal microecology and quality of life in irritable bowel syndrome patients. World J Gastroenterol 10: 1802-1805, 2004

96. Talukder S: Effect of dietary fiber on properties and acceptance of meat products: a review. Crit Rev Food Sci Nutr 55: 1005-1011, 2015

97. Bijkerk CJ, Muris JW, Knottnerus JA, Hoes AW and de Wit NJ: Systematic review: the role of different types of fibre in the treatment of irritable bowel syndrome. Aliment Pharmacol Ther 19: 245-251, 2004.

98. Quartero AO, Meineche-Schmidt V, Muris J, Rubin G and de Wit N: Bulking agents, antispasmodic and antidepressant medication for the treatment of irritable bowel syndrome. Cochrane Database Syst Rev 18: CD003460, 2005.

99. Akehurst R and Kaltenthaler E: Treatment of irritable bowel syndrome: a review of randomised controlled trials. Gut 48 272-282, 2001.

100.Ford AC, Moayyedi P, Lacy BE, Lembo AJ, Saito YA, Schiller LR, Soffer EE, Spiegel BM and Quigley EM; Task Force on the Management of Functional Bowel Disorders: American College of Gastroenterology monograph on the management of irritable bowel syndrome and chronic idiopathic constipation. Am J Gastroenterol 109 (Suppl 1): S2-S26, 2014.
101. Parr NJ, Grime JS, Baxter JN, Critchley M and Mackie CR: Small bowel resistances and the gastroduodenal brake. Gut 28 950-954, 1987

102. White CM, Poxon V and Alexander-Williams J: Effects of nutrient liquids on human gastroduodenal motor activity. Gut 24: 1109-1116, 1983

103. Vidon N, Chaussade S, Merite F, Huchet B, Franchisseur C and Bernier JJ: Inhibitory effect of high caloric load of carbohydrates or lipids on human pancreatic secretions: a jejunal brake. Am J Clin Nutr 50: 231-236, 1989.

104. Vidon N, Pfeiffer A, Franchisseur C, Bovet M, Rongier M and Bernier JJ: Effect of different caloric loads in human jejunum on meal-stimulated and nonstimulated biliopancreatic secretion. Am J Clin Nutr 47: 400-405, 1988.

105. Cunningham KM, Daly J, Horowitz $M$ and Read NW: Gastrointestinal adaptation to diets of differing fat composition in human volunteers. Gut 32: 483-486, 1991.

106. Boyd KA, O'Donovan DG, Doran S, Wishart J, Chapman IM, Horowitz $\mathrm{M}$ and Feinle C: High-fat diet effects on gut motility, hormone, and appetite responses to duodenal lipid in healthy men. Am J Physiol Gastrointest Liver Physiol 284: G188-G196, 2003.

107. Lin HC, Zhao XT and Wang L: Jejunal brake: inhibition of intestinal transit by fat in the proximal small intestine. Dig Dis Sci 41: 326-329, 1996.

108. Spiller RC, Trotman IF, Higgins BE, Ghatei MA, Grimble GK, Lee YC, Bloom SR, Misiewicz JJ and Silk DB: The ileal brake - inhibition of jejunal motility after ileal fat perfusion in man. Gut 25: 365-374, 1984

109. Salvioli B, Serra J, Azpiroz F and Malagelada JR: Impaired small bowel gas propulsion in patients with bloating during intestinal lipid infusion. Am J Gastroenterol 101: 1853-1857, 2006.

110. Simrén M, Abrahamsson H and Björnsson ES: Lipid-induced colonic hypersensitivity in the irritable bowel syndrome: the role of bowel habit, sex, and psychologic factors. Clin Gastroenterol Hepatol 5: 201-208, 2007.

111. Caldarella MP, Milano A, Laterza F, Sacco F, Balatsinou C, Lapenna D, Pierdomenico SD, Cuccurullo F and Neri M: Visceral sensitivity and symptoms in patients with constipation- or diarrhea-predominant irritable bowel syndrome (IBS): effect of a low-fat intraduodenal infusion. Am J Gastroenterol 100: 383-389, 2005.

112. Gibson PR, Barrett JS and Muir JG: Functional bowel symptoms and diet. Intern Med J 43: 1067-1074, 2013.

113. Windey K, De Preter V and Verbeke K: Relevance of protein fermentation to gut health. Mol Nutr Food Res 56: 184-196, 2012.

114. Smith EA and Macfarlane GT: Dissimilatory amino acid metabolism in human colonic bacteria. Anaerobe 3 : 327-337, 1997.

115. Blachier F, Mariotti F, Huneau JF and Tomé D: Effects of amino acid-derived luminal metabolites on the colonic epithelium and physiopathological consequences. Amino Acids 33: $547-562,2007$.

116. Vazquez-Roque MI, Camilleri M, Smyrk T, Murray JA, Marietta E, O'Neill J, Carlson P, Lamsam J, Janzow D, Eckert D, et al: A controlled trial of gluten-free diet in patients with irritable bowel syndrome-diarrhea: effects on bowel frequency and intestinal function. Gastroenterology 144: 903-911, 2013.

117. Talley NJ: Dietary modification as a treatment for irritable bowel syndrome. Gastroenterol Hepatol 8: 552-554, 2012.

118. Gibson PR and Shepherd SJ: Food choice as a key management strategy for functional gastrointestinal symptoms. Am J Gastroenterol 107: 657-667, 2012.

119. Sandström O and El-Salhy M: Ageing and endocrine cells of human duodenum. Mech Ageing Dev 108: 39-48, 1999.

120. Sternini C, Anselmi L and Rozengurt E: Enteroendocrine cells: a site of 'taste' in gastrointestinal chemosensing. Curr Opin Endocrinol Diabetes Obes 15: 73-78, 2008.

121. Moran GW, Leslie FC, Levison SE, Worthington $\mathrm{J}$ and McLaughlin JT: Enteroendocrine cells: neglected players in gastrointestinal disorders? Therap Adv Gastroenterol 1: 51-60, 2008.

122. Moran-Ramos S, Tovar AR and Torres N: Diet: friend or foe of enteroendocrine cells - how it interacts with enteroendocrine cells. Adv Nutr 3: 8-20, 2012.

123. Buffa R, Capella C, Fontana P, Usellini L and Solcia E: Types of endocrine cells in the human colon and rectum. Cell Tissue Res 192: 227-240, 1978. 
124.Barker $\mathrm{N}$ and Clevers $\mathrm{H}$ : Tracking down the stem cells of the intestine: strategies to identify adult stem cells. Gastroenterology 133: 1755-1760, 2007.

125. Sandstrom O and El-Salhy M: Age-related changes in neuroendocrine system of the gut. A possible role in the pathogenesis of gastrointestinal disorders in the elderly. Minireview based on a doctoral thesis. Ups J Med Sci 106: 81-97, 2001.

126. Barker N, van de Wetering $\mathrm{M}$ and Clevers $\mathrm{H}$ : The intestinal stem cell. Genes Dev 22: 1856-1864, 2008.

127. May CL and Kaestner KH: Gut endocrine cell development. Mol Cell Endocrinol 323: 70-75, 2010.

128. Korinek V, Barker N, Moerer P, van Donselaar E, Huls G, Peters PJ and Clevers H: Depletion of epithelial stem-cell compartments in the small intestine of mice lacking Tcf-4. Nat Genet 19: 379-383, 1998

129. Cheng $\mathrm{H}$ and Leblond CP: Origin, differentiation and renewal of the four main epithelial cell types in the mouse small intestine V. Unitarian theory of the origin of the four epithelial cell types. Am J Anat 141: 537-561, 1974

130. Fontaine J, Le Lièvre C and Le Douarin NM: What is the developmental fate of the neural crest cells which migrate into the pancreas in the avian embryo? Gen Comp Endocrinol 33: 394-404, 1977.

131.Le Douarin NM and Teillet MA: The migration of neural crest cells to the wall of the digestive tract in avian embryo. J Embryol Exp Morphol 30: 31-48, 1973.

132. Rawdon BB and Andrew A: Origin and differentiation of gut endocrine cells. Histol Histopathol 8: 567-580, 1993.

133. Hoffman J, Kuhnert F, Davis CR and Kuo CJ: Wnts as essential growth factors for the adult small intestine and colon. Cell Cycle 3: 554-557, 2004.

134. Höcker M and Wiedenmann B: Molecular mechanisms of enteroendocrine differentiation. Ann N Y Acad Sci 859: 160-174, 1998

135. Inokuchi H, Fujimoto S and Kawai K: Cellular kinetics of gastrointestinal mucosa, with special reference to gut endocrine cells. Arch Histol Jpn 46: 137-157, 1983.

136. Tolhurst G, Reimann F and Gribble FM: Intestinal sensing of nutrients. Handb Exp Pharmacol 209: 309-335, 2012.

137. Lee J, Cummings BP, Martin E, Sharp JW, Graham JL, Stanhope KL, Havel PJ and Raybould HE: Glucose sensing by gut endocrine cells and activation of the vagal afferent pathway is impaired in a rodent model of type 2 diabetes mellitus. Am J Physiol Regul Integr Comp Physiol 302: R657-R666, 2012.

138. Parker HE, Reimann F and Gribble FM: Molecular mechanisms underlying nutrient-stimulated incretin secretion. Expert Rev Mol Med 12: e1, 2010.

139. Raybould HE: Nutrient sensing in the gastrointestinal tract: possible role for nutrient transporters. J Physiol Biochem 64: 349-356, 2008.

140. San Gabriel A, Nakamura E, Uneyama H and Torii K: Taste, visceral information and exocrine reflexes with glutamate through umami receptors. J Med Invest 56 (Suppl): 209-217, 2009

141. Rudholm T, Wallin B, Theodorsson E, Näslund E and Hellström PM: Release of regulatory gut peptides somatostatin neurotensin and vasoactive intestinal peptide by acid and hyperosmolal solutions in the intestine in conscious rats. Regul Pept 152: 8-12, 2009.

142. Sternini C: Taste receptors in the gastrointestinal tract. IV. Functional implications of bitter taste receptors in gastrointestinal chemosensing. Am J Physiol Gastrointest Liver Physiol 292: G457-G461, 2007.

143. Buchan AM: Nutrient tasting and signaling mechanisms in the gut III. Endocrine cell recognition of luminal nutrients. Am J Physiol 277: G1103-G1107, 1999.

144. Montero-Hadjadje M, Elias S, Chevalier L, Benard M, Tanguy Y, Turquier V, Galas L, Yon L, Malagon MM, Driouich A, et al: Chromogranin A promotes peptide hormone sorting to mobile granules in constitutively and regulated secreting cells: role of conserved $\mathrm{N}$ - and C-terminal peptides. J Biol Chem 284 $12420-12431,2009$.

145. Shooshtarizadeh P, Zhang D, Chich JF, Gasnier C, Schneider F, Haïkel Y, Aunis D and Metz-Boutigue MH: The antimicrobial peptides derived from chromogranin/secretogranin family, new actors of innate immunity. Regul Pept 165: 102-110, 2010.

146. El-Salhy M, Seim I, Chopin L, Gundersen D, Hatlebakk JG and Hausken T: Irritable bowel syndrome: the role of gut neuroendocrine peptides. Front Biosci 4: 2783-2800, 2012.

147. Gunawardene AR, Corfe BM and Staton CA: Classification and functions of enteroendocrine cells of the lower gastrointestinal tract. Int J Exp Pathol 92: 219-231, 2011.
148.El-Salhy M: The possible role of the gut neuroendocrine system in diabetes gastroenteropathy. Histol Histopathol 17: $1153-1161,2002$

149. Debas HT and Mulvihill SJ: Neuroendocrine design of the gut. Am J Surg 161: 243-249, 1991.

150. Goyal RK and Hirano I: The enteric nervous system. N Engl J Med 334: 1106-1115, 1996.

151. McConalogue K and Furness JB: Gastrointestinal neurotransmitters. Baillieres Clin Endocrinol Metab 8: 51-76, 1994.

152. Gearry RB, Irving PM, Barrett JS, Nathan DM, Shepherd SJ and Gibson PR: Reduction of dietary poorly absorbed short-chain carbohydrates (FODMAPs) improves abdominal symptoms in patients with inflammatory bowel disease-a pilot study. J Crohn's Colitis 3: 8-14, 2009.

153. Halmos EP, Power VA, Shepherd SJ, Gibson PR and Muir JG A diet low in FODMAPs reduces symptoms of irritable bowel syndrome. Gastroenterology 146: 67-75, 2014.

154. Shepherd SJ1, Parker FC, Muir JG and Gibson PR: Dietary triggers of abdominal symptoms in patients with irritable bowel syndrome: randomized placebo-controlled evidence. Clin Gastroenterol Hepatol 6: 765-771, 2008.

155. Staudacher HM, Lomer MC, Anderson JL, Barrett JS, Muir JG, Irving PM and Whelan K: Fermentable carbohydrate restriction reduces luminal bifidobacteria and gastrointestinal symptoms in patients with irritable bowel syndrome. J Nutr 142: 1510-1518, 2012

156. Staudacher HM, Whelan K, Irving PM and Lomer MC: Comparison of symptom response following advice for a diet low in fermentable carbohydrates (FODMAPs) versus standard dietary advice in patients with irritable bowel syndrome. J Hum Nutr Diet 24: 487-495, 2011.

157. Wilder-Smith CH, Materna A, Wermelinger C and Schuler J: Fructose and lactose intolerance and malabsorption testing: the relationship with symptoms in functional gastrointestinal disorders. Aliment Pharmacol Ther 37: 1074-1083, 2013.

158. Halmos EP, Christophersen CT, Bird AR, Shepherd SJ, Gibson PR and Muir JG: Diets that differ in their FODMAP content alter the colonic luminal microenvironment. Gut 64: 93-100, 2015.

159. Hustoft TN, Hausken T, Ystad SO, Valeur J, Brokstad K, Hatlebakk JG and Lied GA: Effects of varying dietary content of fermentable short-chain carbohydrates on symptoms, fecal microenvironment, and cytokine profiles in patients with irritable bowel syndrome. Neurogastroenterol Motil 29: 2017. doi: $10.1111 / \mathrm{nmo} .12969$.

160. Böhn L, Störsrud S and Simrén M: Nutrient intake in patients with irritable bowel syndrome compared with the general population. Neurogastroenterol Motil 25: 23-30, 2013.

161. Ligaarden SC, Lydersen S and Farup PG: Diet in subjects with irritable bowel syndrome: a cross-sectional study in the general population. BMC Gastroenterol 12: 61, 2012.

162. Williams EA, Nai X and Corfe BM: Dietary intakes in people with irritable bowel syndrome. BMC Gastroenterol 11: 9, 2011.

163. Halpert A, Dalton CB, Palsson O, Morris C, Hu Y, Bangdiwala S, Hankins J, Norton N and Drossman D; National Survey on Patient Educational Needs in IBS and Development and Validation of the Patient Educational Needs Questionnaire (PEQ): What patients know about irritable bowel syndrome (IBS) and what they would like to know. National Survey on Patient Educational Needs in IBS and development and validation of the Patient Educational Needs Questionnaire (PEQ). Am J Gastroenterol 102: 1972-1982, 2007.

164. El-Salhy M and Gundersen D: Diet in irritable bowel syndrome. Nutr J 14: 36, 2015

165. El-Salhy M, Lilleb $\varnothing$ E, Reinemo A, Salmelid L and Hausken T: Effects of a health program comprising reassurance, diet management, probiotics administration and regular exercise on symptoms and quality of life in patients with irritable bowel syndrome. Gastroenterol Insights 2: 1-6, 2010.

166. Mazzawi T, Hausken T, Gundersen D and El-Salhy M: Effects of dietary guidance on the symptoms, quality of life and habitual dietary intake of patients with irritable bowel syndrome. Mol Med Rep 8: 845-852, 2013.

167. Roalfe AK, Roberts LM and Wilson S: Evaluation of the Birmingham IBS symptom questionnaire. BMC Gastroenterol 8: 30,2008

168. Patrick DL, Drossman DA, Frederick IO, DiCesare J and Puder KL: Quality of life in persons with irritable bowel syndrome: development and validation of a new measure. Dig Dis Sci 43: 400-411, 1998. 
169. Drossman DA, Patrick DL, Whitehead WE, Toner BB, Diamant NE, Hu Y, Jia H and Bangdiwala SI: Further validation of the IBS-QOL: a disease-specific quality-of-life questionnaire. Am J Gastroenterol 95: 999-1007, 2000.

170. Talley NJ, Verlinden M and Jones M: Quality of life in functional dyspepsia: responsiveness of the Nepean Dyspepsia Index and development of a new 10-item short form. Aliment Pharmacol Ther 15: 207-216, 2001.

171. Arslan G, Lind R, Olafsson S, Florvaag E and Berstad A: Quality of life in patients with subjective food hypersensitivity: applicability of the 10-item short form of the Nepean Dyspepsia Index. Dig Dis Sci 49: 680-687, 2004.

172. Mazzawi T and El-Salhy M: Dietary guidance and ileal enteroendocrine cells in patients with irritable bowel syndrome. Exp Ther Med 12: 1398-1404, 2016.

173. Mazzawi T, Gundersen D, Hausken T and El-Salhy M: Increased gastric chromogranin A cell density following changes to diets of patients with irritable bowel syndrome. Mol Med Rep 10: 2322-2326, 2014.

174. Mazzawi T, Hausken T, Gundersen D and El-Salhy M: Dietary guidance normalizes large intestinal endocrine cell densities in patients with irritable bowel syndrome. Eur J Clin Nutr 70: $175-181,2016$

175. Mazzawi T and El-Salhy M: Changes in duodenal enteroendocrine cells in patients with irritable bowel syndrome following dietary guidance. Exp Biol Med: 2017. doi.org/10.1177/1535370217699537.
176. Deftos LJ: Chromogranin A: its role in endocrine function and as an endocrine and neuroendocrine tumor marker. Endocr Rev 12: 181-187, 1991.

177. Taupenot L, Harper KL and O'Connor DT: The chromogranin-secretogranin family. N Engl J Med 348: 1134-1149, 2003.

178. Wiedenmann B and Huttner WB: Synaptophysin and chromogranins/secretogranins - widespread constituents of distinct types of neuroendocrine vesicles and new tools in tumor diagnosis. Virchows Arch B Cell Pathol Incl Mol Pathol 58: 95-121, 1989.

179. Mazzawi T and El-Salhy M: Changes in small intestinal chromogranin A-immunoreactive cell densities in patients with irritable bowel syndrome after receiving dietary guidance. Int J Mol Med 37: 1247-1253, 2016.

180. Mazzawi T, Gundersen D, Hausken T and El-Salhy M: Increased chromogranin a cell density in the large intestine of patients with irritable bowel syndrome after receiving dietary guidance. Gastroenterol Res Pract 2015: 823897, 2015.

181. Mazzawi T, Hausken T, Gundersen D and El-Salhy M: Effect of dietary management on the gastric endocrine cells in patients with irritable bowel syndrome. Eur J Clin Nutr 69: 519-524, 2015. 